\title{
The Existing Challenges of Heritage Management in Gondar World Heritage Sites: A Case Study on Fasil Ghebbi and the Baths
}

\author{
Shegalem Fekadu Mengstie ${ }^{1}$ \\ Lecturer at the University of Gondar, Department of History and Heritage Management
}

\begin{abstract}
Heritage management is an administrative means by which heritage resources are protected from natural and manmade cause of deterioration. The town of Gondar is located in Northwestern Ethiopia and it has outstanding and outstay world cultural heritage resources situated at its hub. However, these stunning properties are threatened with multidimensional heritage management problems. So, this paper tried to identify the main and existing challenges and show the severity of the problems in comparison with different case studies in the world. It compiled through qualitative research method with descriptive research design. And data were collected through survey, participant observation and photographic documentation and interpretation. The collected data also compiled by qualitative method of data analysis. The main and the existing challenges of Gondar's world heritage sites, specifically of the Fasil Ghebbi and the baths are plant overgrowth, human activities on the immediate vicinity of the sites (that leads to vibration of the structures and noise disturbance), negligence, visitors pressure, improper conservation, nonexistence or inapplicability of heritage management plan, Lack of tourist follow-up system as a means for deliberate graffiti of heritages, lack of cooperation among the concerned bodies and unavailability of directions and instructions. Finally, it is highly recommended to made immediate intervention on each problems.
\end{abstract}

Keywords: Challenges, Heritage Management, World Heritage, Gondar and Fasil Ghebbi

DOI: $10.7176 / \mathrm{JTHS} / 43-02$

Publication date:September $30^{\text {th }} 2019$

\section{I.Introduction}

Cultural properties are important to us and are indispensable to our world; from them we get information about our past, history, culture, traditions and social norms, this Provide basis for technological advancement in all aspects of our life (Yoichi and Nishiyama, 1993). It is to mean that, our cultural properties are the witness about our past and a base for our day today activities particularly for the technological innovations.

Deterioration of ancient buildings is caused by not only due to the age of the monuments but also mainly because of several natural factors such as rainfall, temperature, wind blowing, and humidity that could cause demolition of the structures in the course of time (El-Gohary, and Al-Shorman 2009as cited in Fikadu K. 2012).Whereas, Fire, armed conflicts, illegal activities and illicit trafficking of heritages are some example of anthropogenic factors which can demolish heritage resources. Therefore, cause of deterioration for a particular heritage site should be identified (either natural or anthropogenic) and tackled. And it is the first and foremost action in heritage conservation and management. Stones of aged buildings mostly deteriorate as the temperature fluctuates daily and seasonally, since freezing-thawing process, which has huge impact on the deterioration of stone materials, will occur as a result of such fluctuations and solar effect (EsraYaldiz, 2010).Hence, "continuous fluctuating of temperature changes caused the cracks and breaks on stones as a result of the material fatigue" (Küçükkaya 2004 as cited in Esra Yaldiz 2010).

Gondar was founded by Emperor Fasiladas in 1636 and served as a capital of Ethiopia until 1855. Gondar boasts a win of marvelous castles, constructed by the Gondarine emperors, within a high-walled compound with 12 traditional gates, near the center of the town. Gondar hosts also a three story stone pavilion, a short distance out of the palace complex surrounded by a sunken bathing palace of Fasiladas. This neatly walled destruction is still filled with water for the annual celebration of Timkat (Epiphany) celebrations. The Orthodox churches of Gondar, with their unique designs and decorations are equally important architecturally, historically as well as for the paintings on the walls of their holy of holies. On the outskirts of the town are found the ruins of the palace of Empress Mentewab (widow of Bakafa), her banquet halls and Quesquam church, containing the skeletal remains of the empress herself and her son Iyasu II in its crypt. All these castles and churches testify to the quality of Ethiopia's $17^{\text {th }}$ and $18^{\text {th }}$ century's craftsmanship. Due to the stunning, historical and outstanding universal values, the castles inscribed under world heritage list. They were in line with the criteria II(interchange of ideas) and III(cultural tradition). However, these world heritage sites are threatening with different manmade and natural cause of deteriorations. So, this study tried to identify the main problems which challenges for the

${ }^{1}$ MA. In Archaeology and Heritage Management 
Fasil Ghebbi and the baths and recommended the possible solutions.

\section{Method and Material}

The study is mainly focused on the analysis of the existing threats of heritage values on Gondar Castle world heritage site a case studyon the Fasil Ghebbi and the baths. Accordingly, the paper examined through qualitative approach with descriptive research design.

\section{A. Data Collection Methods}

For the successful attainment of this paper, the investigator has used the selected and appropriate data gathering instruments for such kind of thematic area. These are;

\section{a) Survey of the Site}

The researcher has made survey to understand the current/existing challenges of the sites. Through this method, the researcher acquired data about threats surrounding the sites, activities doing inside the enclosure of the sites, cracking of the structure and its cause, environmental related problems(biological problems including plant over growth) affecting the sites, overall heritage handling system, and impact of settlement on heritages.

\section{b) 'Participant' Observation}

The researcher has spent a considerable amount of time in the site with the visitors. He visited the sites many times not as a researcher; just as a tourist/visitor. During that time, the researcher collected the data about how the tourists care about the site or the sense of belongingness, tourist follow-up/management system, disturbance from outside and what tourists did inside the enclosure.

\section{c) Photographic Documentation and Interpretation}

During gathering data through the above methods, the researcher documents all the necessary things through photograph. All the cracks, plant overgrowth, roads and squares on the immediate vicinity of the site, deliberate graffiti on the walls, biological related problems and other challenges ware documented well in photograph. Beside of documentation, all photos were interpreted professionally.

B. Method of Data Analysis

The collected data through the above mentioned instruments were analyzed through qualitative method of data analysis in support of comparison study.

\section{Data Analysis and Interpretation}

In exacerbate condition; the specific heritages (Fasil Ghbi and the baths) are the victim of the following major challenges.

\section{Plant Overgrowth}

The growth of roots and branches of the plants on and around a building can crackdown, break and loosen stones and large fragments of wall due to their physical and mechanical impacts (Lisci et al. 2002 as cited in Fikadu K. 2012). The overgrown and encroaching trees and shrubs are the significant threats facilitating the total demolition of the monumental heritages. Beside to their direct impacts, the plants (the trees and shrubs) grown in and around the monuments allow infestation of animals such as rodents that cause mechanical damages while they dig the monumental grounds to make their habitats within the structures (Fikadu K. 2012).

Likewise in Gondar town heritages are the victim of this kind of problem. Large and small trees (shrubs) are grown over historic structures and practically it leads to the destruction of the structures. The small trees and grasses are affecting the structures by creating algae and fungi (Biological agents). These parasites on the structure decayed the wooden materials in the structure. Whereas the large trees grown on the structure became strong trough time and their root is go down and then tauten the structure by force when it get strong. This problem is extremely affecting at the enclosure of Fasil's bath and palace's of AdiamSegedEyasu. 

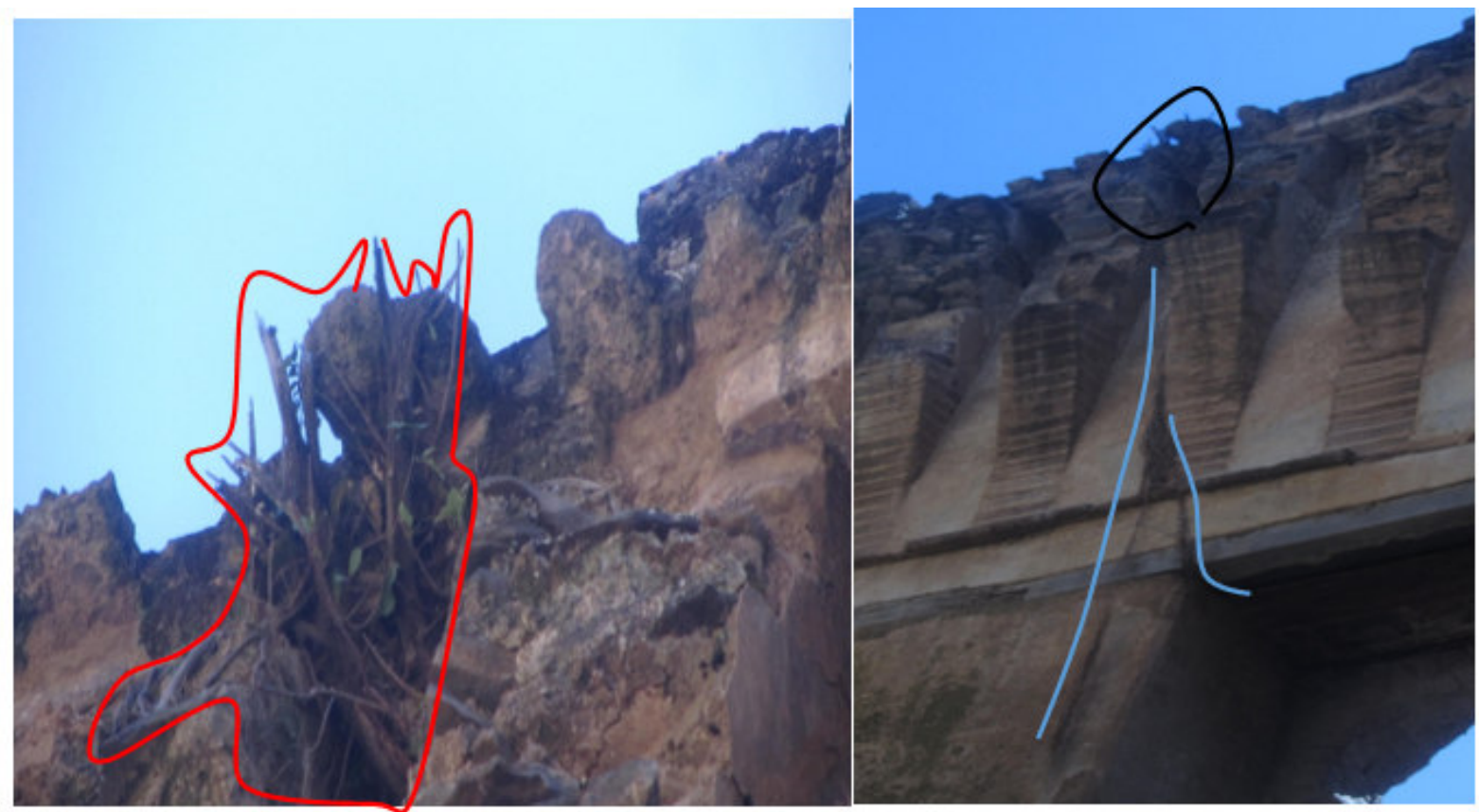

Fig. 1(A),shows the tree grown on the upper and internal wall of the structure at the southeastern facade of AdiamSegedEyasu's Palace and (B), shows how much the root of the tree (shown at A) go down externally and we can estimate the other part of the root is go deep inside the structure to this much(Photo by the researcher, December 2018).

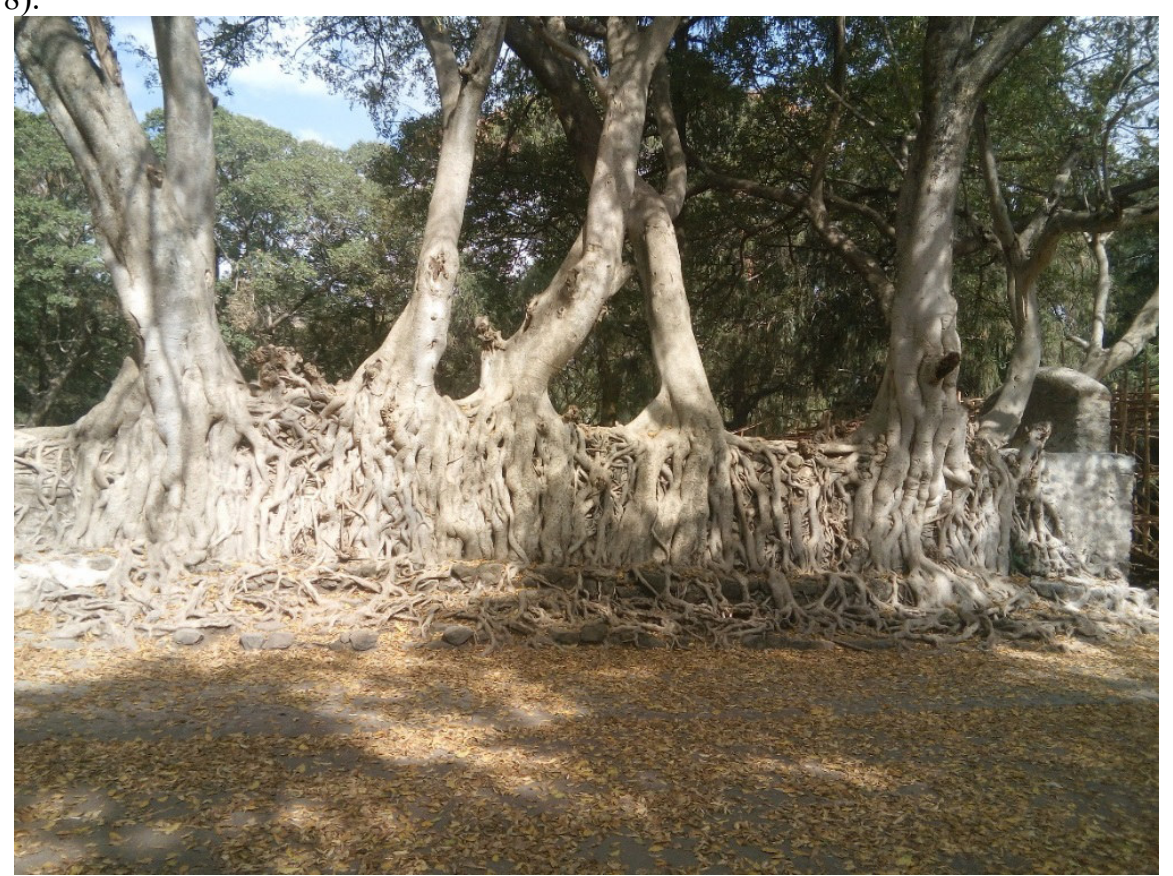

Fig.2, The western external part ofthefaçade of the main bath (photo by the researcherFebruary, 2019)

As we can see on the above image which is the western part of the main bath of Fasil, approximately $5 \mathrm{~m}$ of the historic building is totally demolished by plants grown over it. This means $\sim 5 \mathrm{~m}$ structure is fully lost by the root of the trees. First it was grown like as the small trees displayed in AdiamSegedEyasus's palace. 


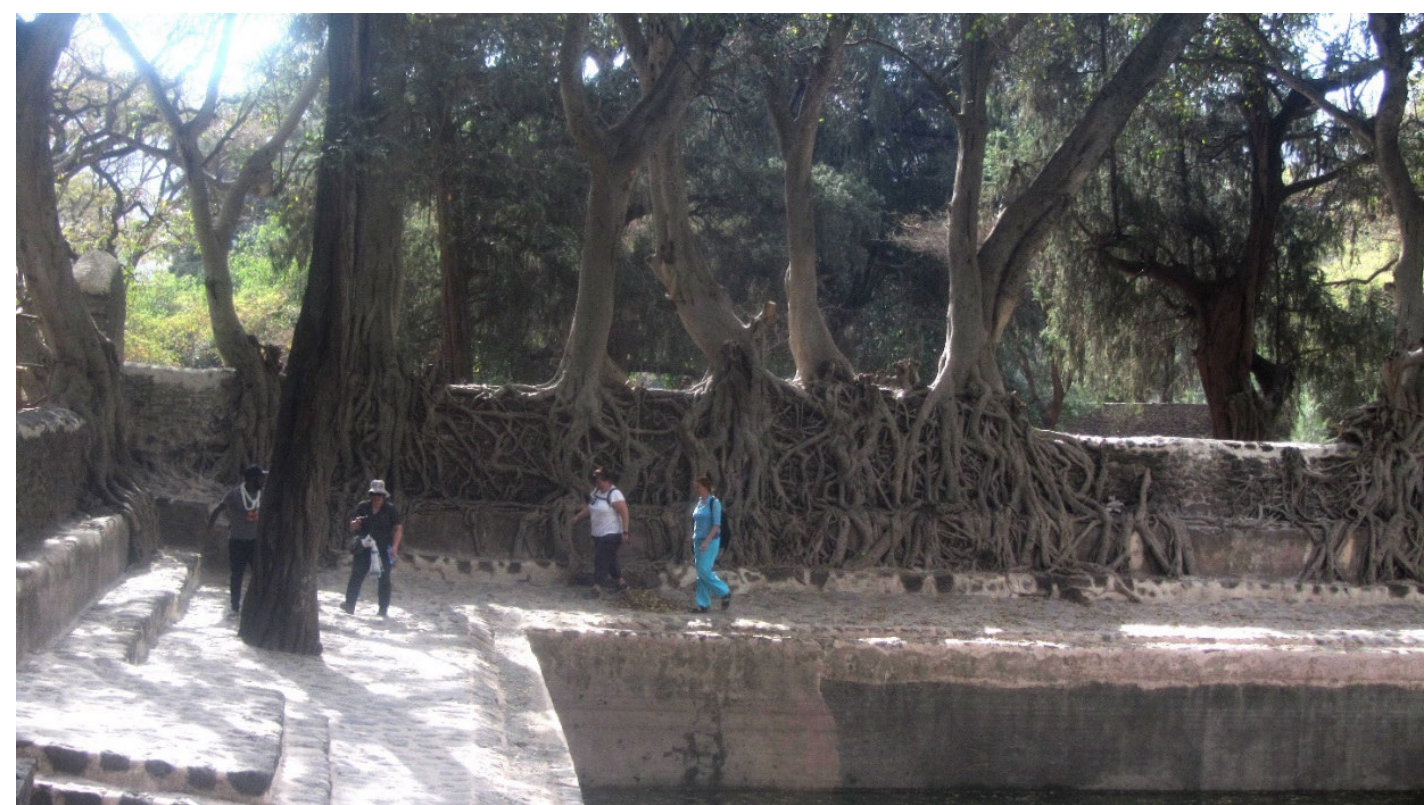

Fig.3 The western eternal part of façade of the main bath (photo by the researcher February, 2019)

In the external part of the structure the building is totally covered with the root of the trees. Whereas, in the eternal part of the structure (fig.3) indicates how the roots are tauten the structure; because the original building is displayed under the roots. In general, plant overgrowth is a common and serious problem of heritages in Gondar town and specifically on heritages in Fasil Ghebbi and the baths. There are shrubs, grasses and large trees are grown over the structures almost on every built heritages of Gondar town.

\section{Human Activities on the Immediate Vicinity of the Heritages}

In the principles of heritage management, a site should have identified core zone, buffer zone and transition zone. Particularly if the site is a world heritage, it should have these zones as a minimum requirement to inscribe on the list. Any activity that may affect on the existence of a heritage is not acceptable in any circumstances. And even the international standard indicated through the following diagram.

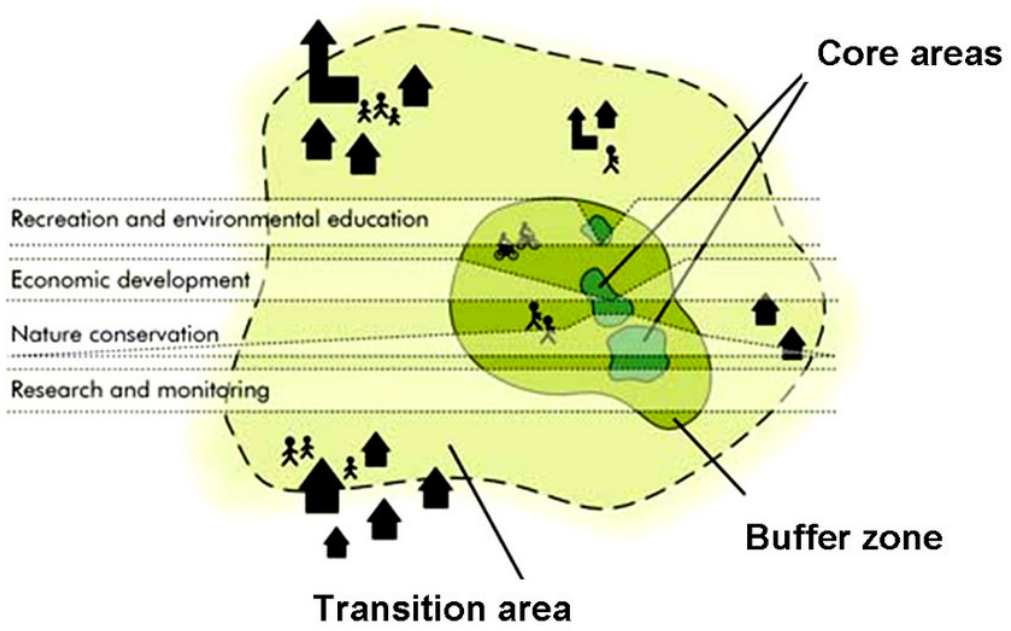

Fig.4, Zoning of a particular site (core area, buffer zone, and transition area) (taken from online in January, 2019)

However, in the case of heritages in Gondar (Fasil Ghebbi and the baths) they lack these zones or this world heritage management principle is not practicing in action. Due to this, parking, roads, different constructions and squares (different mass activities are performed) are found on the immediate vicinity of all sites. The image below Fig (B) is on the western part or at the exit side of the castles. Cars are parking almost by touching the historic structures (heritages). So, undoubtedly it will destruct the site in different ways. And the image (Fig A) is the heritage/structure which is erected almost on the asphalt road on the side of Enkoyeber (south of the castle). It is highly susceptible to car crash and vibration happening by large vans passes through. 


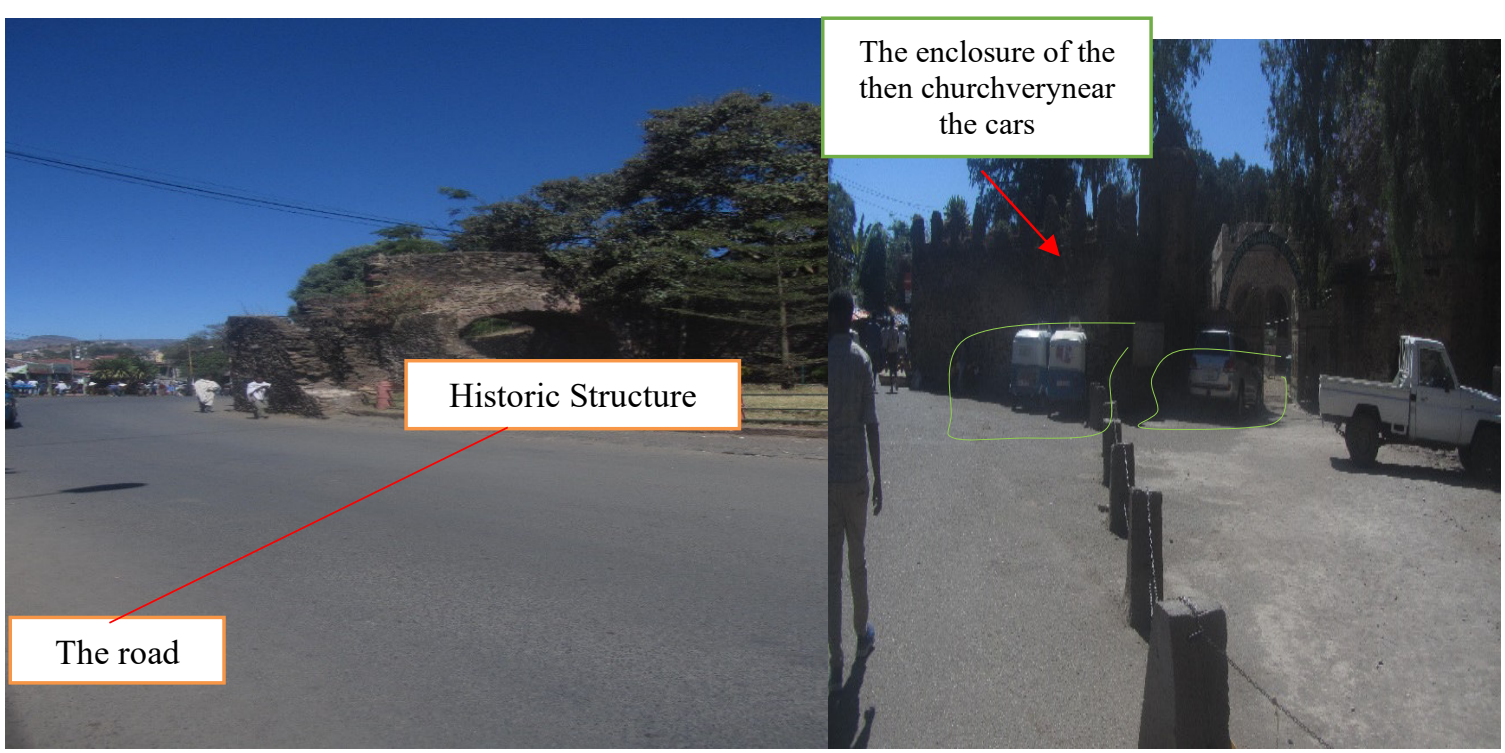

Fig.5. the historic structures found almost on the road (A, left), and parking almost by touching the historic structure (B, right) (Photo taken by the researcher, January 2019).

In line with the above facts, those problems may leads to different sub problems. So, some of the problems that are the result of such activity is presented below.

\section{A. Vibration of the Structures}

Vibrations resulting from the movement of vehicles around the palace leading to the collapse of the foundations and that needs maintenance and repair (FirasAlawneh, etl. 2012).Similarly, in Gondar town, since the roadspass through almost by touching the core area of the site or the enclosure, it makes a vibration when a van passes through the road. And even there is a road under the bridge. This is a serious problem and even the case will make the site under endangered list. As we have seen above there is no specified place for parking. So, in most

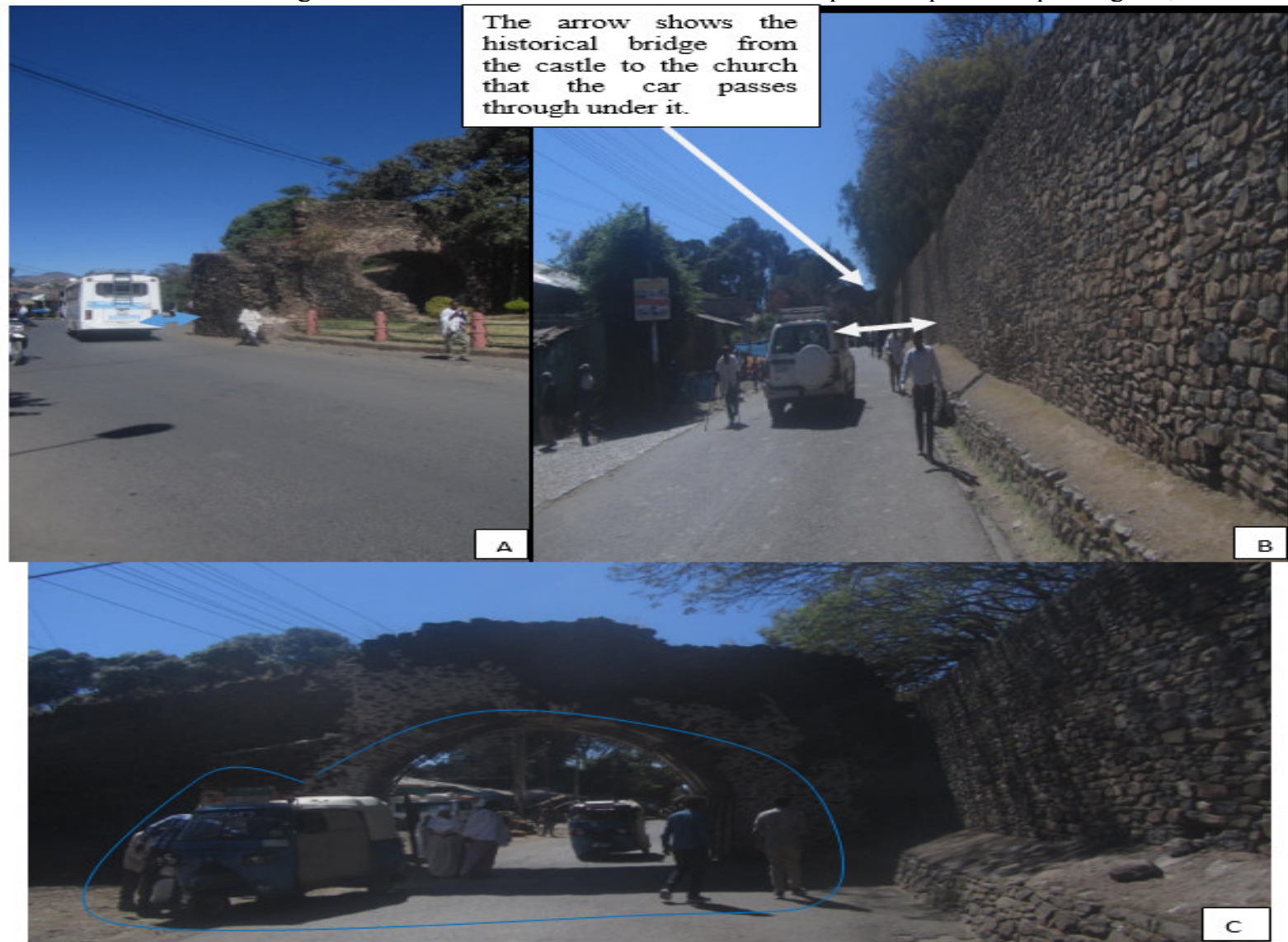

Fig.6 a large bus passes near the historic structure (A), a car that will passes through the historic bridge displayed below there (B) and the bridge over the road and activities under it (Photo by the researcher, January 2019). 


\section{B. Noise Disturbance}

In our natural environment pollution is the single biggest threat to our current way of life and even for cultural heritages. There are a number of variable sources of environment pollution, including air pollution, water pollution, ground water pollution, and land pollution. Of course noise pollution is another growing source of problematic pollution in our world as well (Firas Alawneh1, etl. 2012). Similarly in Gondar town heritages are affected by noise pollution or noise disturbance. On the immediate environs of the FasilGhebbi and the Fasil bath, different human activities are undertaken. For instance, the square on the northwest of the FasilGhebbiimmediately under the fence or enclosure is found and different mass events are performed and it used as a football field and even motorcycle practitioners are practicing there. So, the noise from the events, the football players and the cars are directly affects or disturb the attention of the visitors inside the castle in addition to its disturbance to the site.

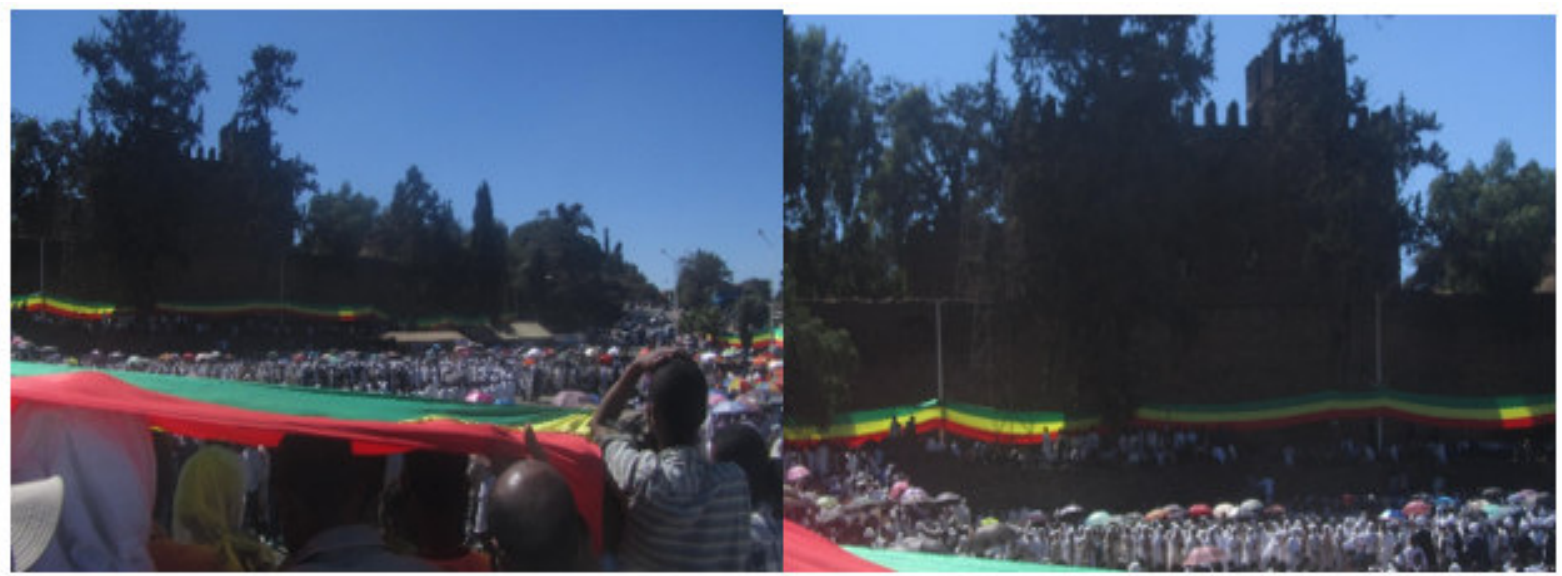

Fig.7 the event prepared on the square which is under the Fasil Ghebbiwhen an exile bishop (Abune Merqoreyos) came to the town (Photo taken by the researcher, January 2019).

\section{Negligence}

Negligence is perhaps the most insidious threat, whether by deliberate intent, lack of awareness or concern, or lack of the necessary resources. It is not only the failure to undertake necessary work on cultural buildings and objects; it can also consist of failure to develop appropriate legislation, the failure to observe incompatibilities between different statutory measures or policies, or the failure to undertake necessary research into preventive and remedial measures (Firas Alawneh1, etl. 2012).In short, it is the result of poor attention from all the concerned bodies and commonly observed on heritagesof Gondar town.

Even, the growing of large trees on the structure is the result of carelessness or negligence. As we can see the image below (the readers' right side) trees on the structure grown like that and through time it destruct like the image below displayed on the left side. It is simple to avoid the small trees before they get strong except carelessness/ lack of due attention towards the heritage site.

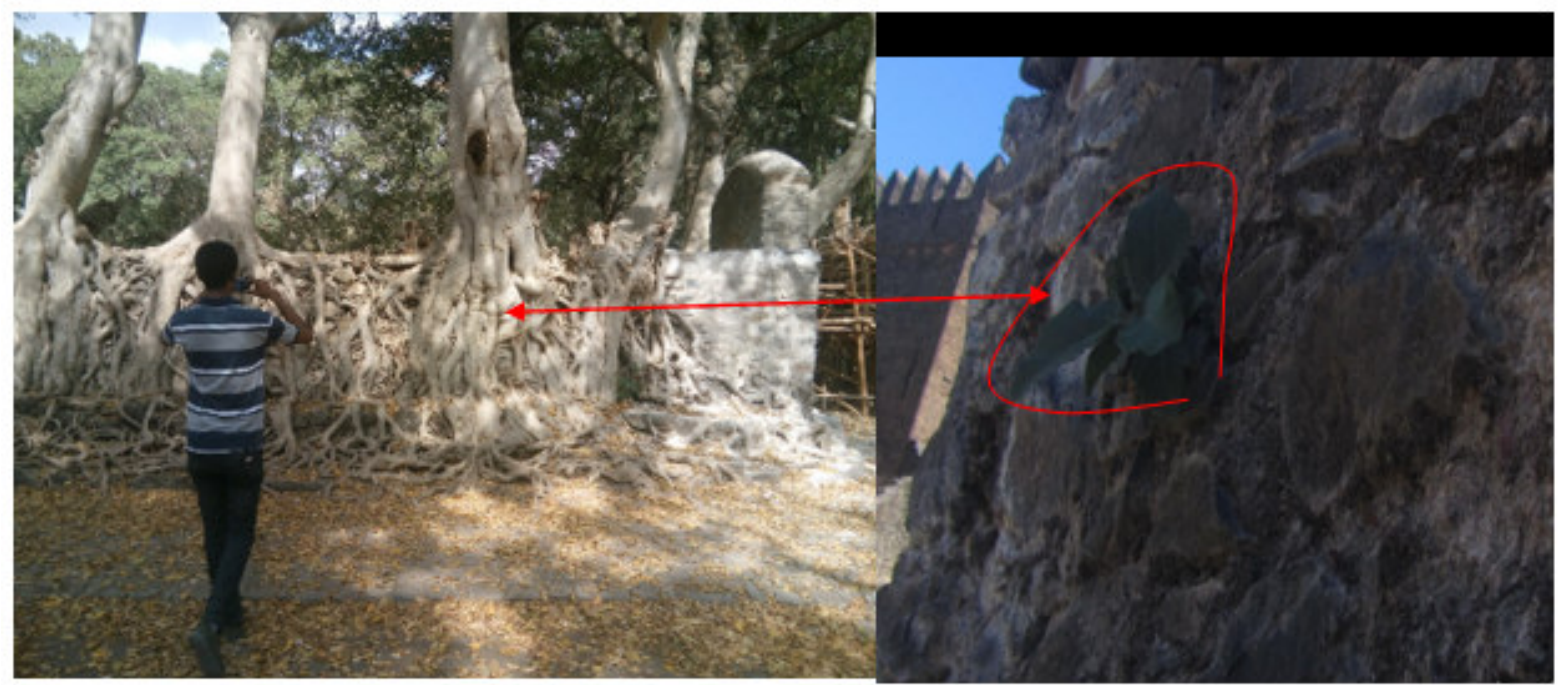

Fig. 8 the structure destructed by big trees at Fasil bath and a small tree growing on the left side of the stair goes to the second floor of Fasil palace (Photo by the researcher, January 2019).

In the case of abandoned structures over the Fasil bath which ware a public bath constructed by Fasilare 
severely neglected. The structures are destructing and almost buried with craps. The peoples living there are damping sweepings/dusts on the historic structures. Plants overgrown, herding animals and settlement inside the enclosure of the sites are destructing the heritages. The following figure shows the ruins of the public baths which was used as hen breeding during the Italian occupation period (1935-1941).

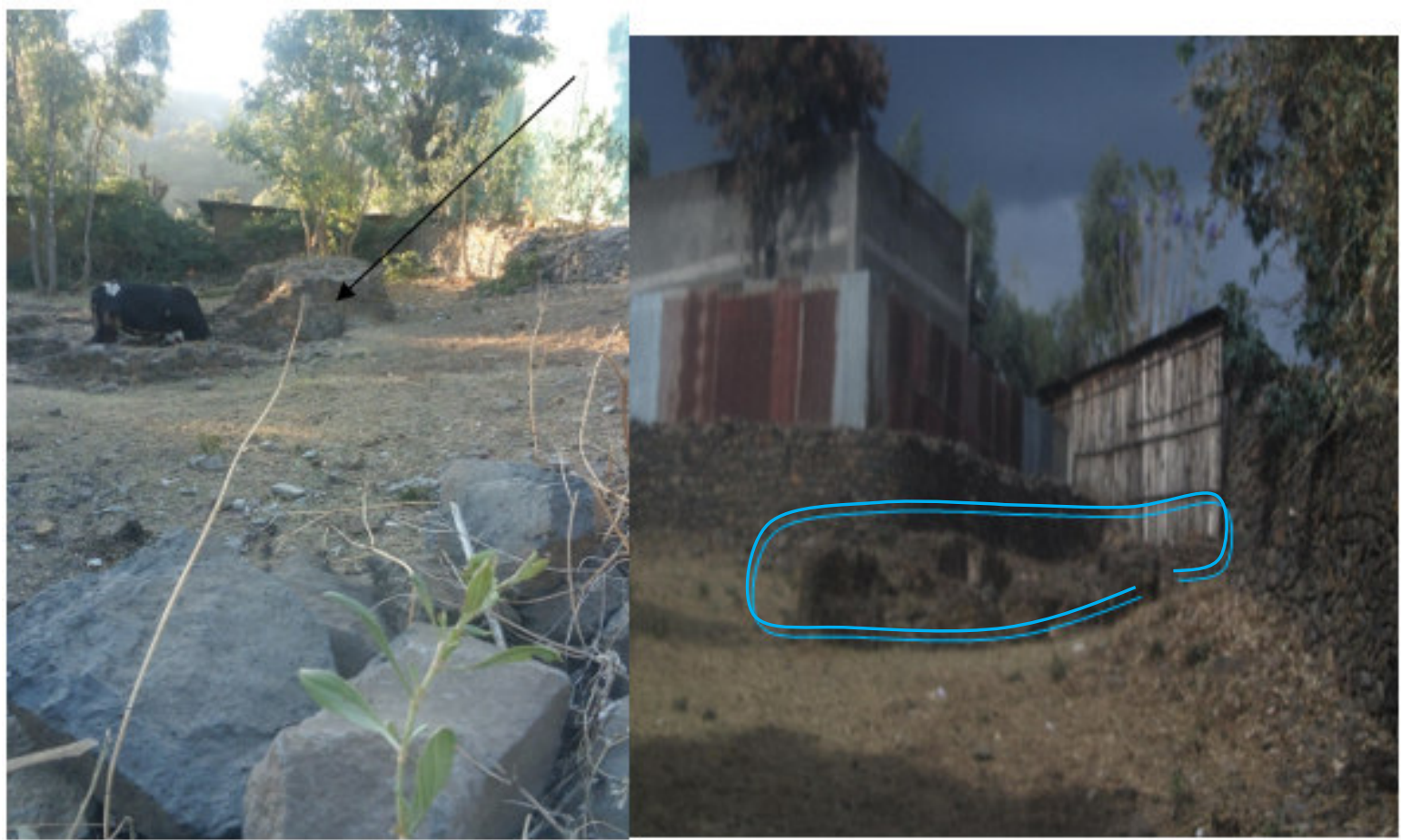

Fig. 9 a circle of ruined structure buried through the accumulation of craps and now a cow is eating a grass in the circle of the structure. This shows how much the historic structure is neglected (reader's left). And the other ruin of a structure which was a public bath and now a new house is constructed over it. The new settlement almost covered the site (reader's right (Photo by the researcher, February 2019).

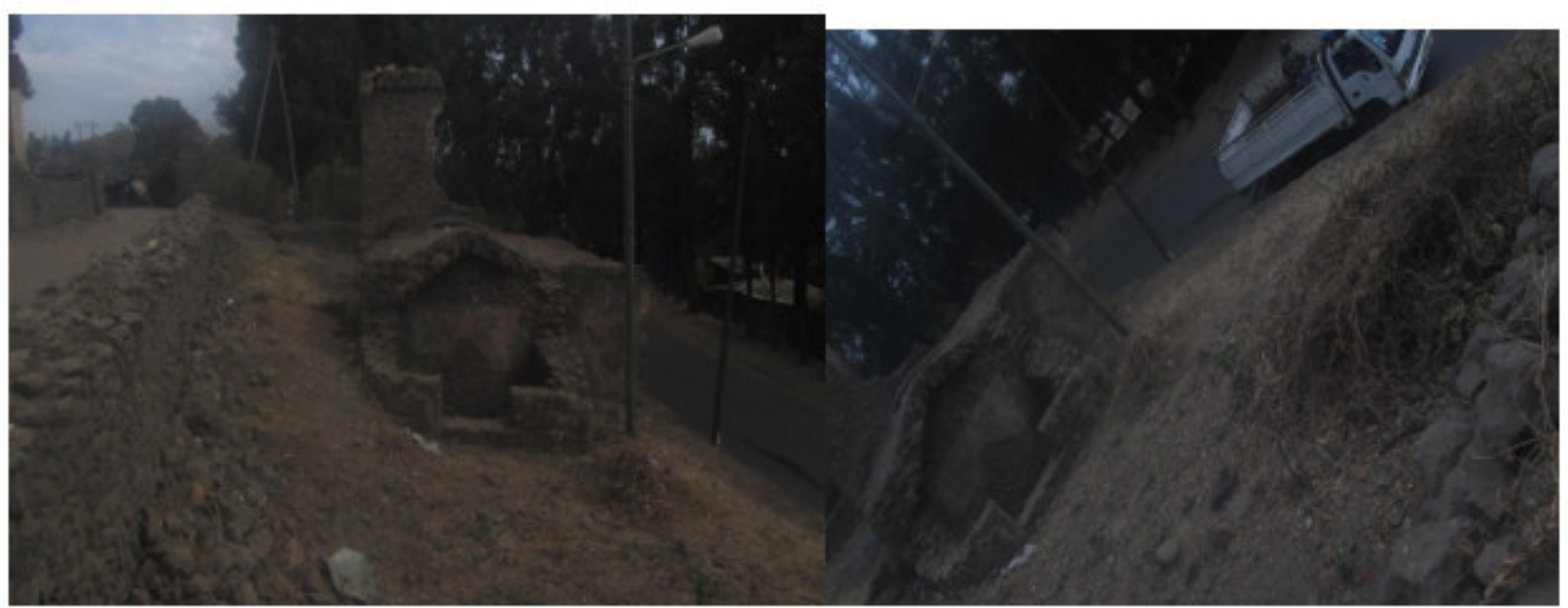

Fig. 10it is also the ruin which was the public bath during the reign of emperor Fasil. And as we can see on the image, it is almost destruct and the compound is full of craps. Roads also encircle the structure in two directions (reader's left). And the right image also shows when the big van passes almost close to the site (reader's right) (Photo by the researcher, February 2019).

Another critical problem in those baths is lack of awareness among the peoples living there. During the researcher's survey, he tried to ask information from them about the ruined structures; however, they don't know about history of these sites. They only know as it was a house for hen breeding during the Italian occupation (1935-1941). In fact, it shows during that time their original value was changed or mistakenly re-used and it might be the reason for the negligence. But the peoples know only the re-used values of those ruined structures. This indicates their awareness about heritage is too low. Frankly speaking, not only the locals even some government officials working in the area also not familiar about this fact. 


\section{Visitors Pressure}

Practice has shown that tourism may benefit local communities in many different ways. In personal terms, sociopolitical terms, economical as well as environmental terms. If the local community takes advantage of the available resources it can maximize their competitiveness. Along with the increase in the number of international and national visitors, the community's profits from tourism increase (Dugulan et al, 2010).However, according to Huibin (2012), there are certain dangers in the exploitation of cultural heritages through tourism. The lack of measures and necessary political action from the responsible bodies not only allows but in fact often encourages the abusive exploitation of cultural property. This often results in the degradation and even destruction of traditional elements.

In case of heritages in Gondar, particularly the domestic tourists who came in group pressurize the sites. Mostly ground plus heritages with wooden floors are seriously damaged. For example, during epiphany celebration domestic mass tourism is highly affecting heritages. As we can see on the image below all the peoples are standing and crowded over the structures of the Fasil bath. Certainly, it leads to crack, distort and removal of the structure.

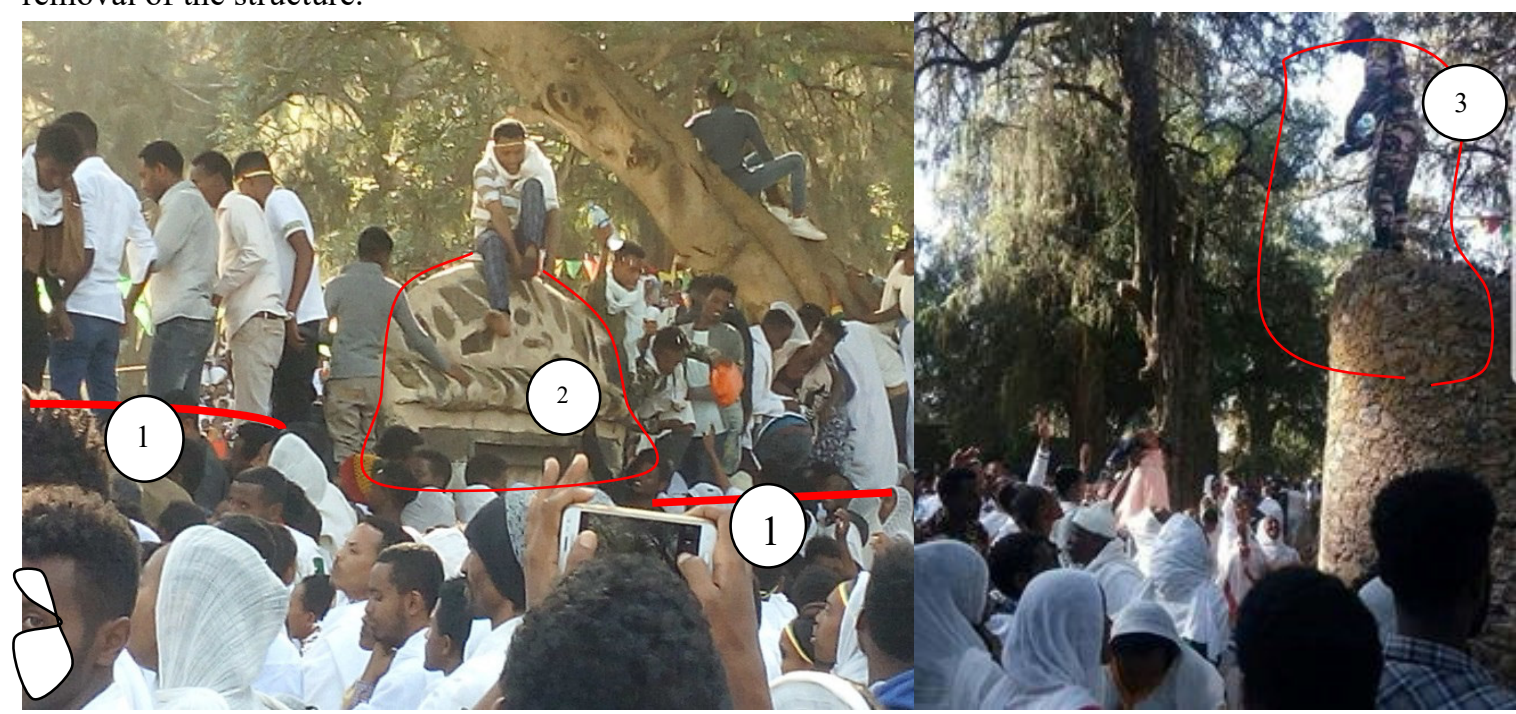

Fig.11Peoples are standing on the historic structure of the bath during epiphany (1), a guy wearing his shoe after baptizing on the peak of the arched door (2) and a soldier also standing on the historic structure and "baptizing" the people (3)(Photo by the researcher, January 2019).

The following image is the second example for how mass tourism challenging heritages in Gondar town. The left photo (A) shows as a person standing for photo on the space at the back side of Fasil palace made out of wood. During the frequent visit of the researchers they saw this trend of having photo on this place. So, this trend on the wooden historical structure is a treat for its destruction. The image on the rightside; (B) alsoshows the defect of wooden floor of Fasil palace through the impact of overcrowded visitors.

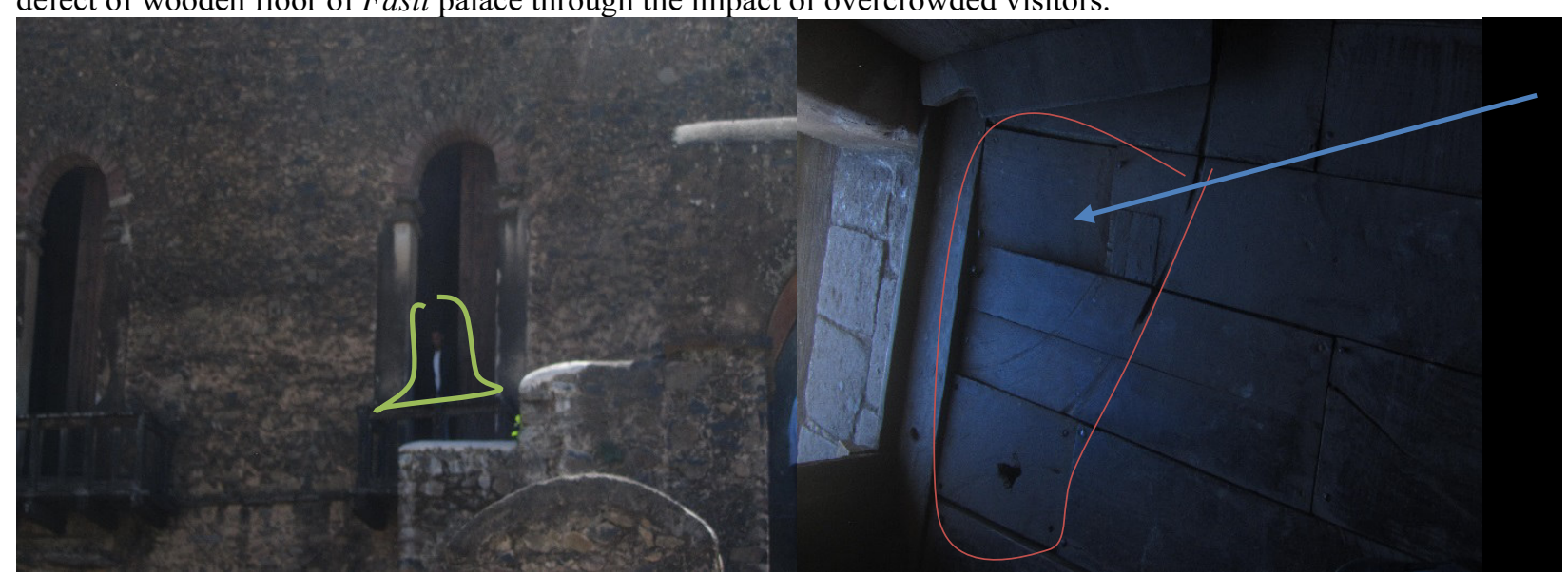

Fig. 12(A), a person standing on the historical wooden structure to have a photo at the back side of the castle of Fasil and (B),the wooden floor of Fasil palace and the circle show the defect of the floor.

Beside of the above stated problems resulting from visitors' pressure, it also leads to abrasion and shear of the structures. Abrasion is the fading up of structure through touching and removing the plaster over the wall by hand. In Fasil castle, all the frames of the door, the window and even the wall are damaging through abrasion 
(see Fig.13 A), whereas, shear is the removal of the parts of the structure in time through frequent uses. So, as we can see on the image below (fig.13B) heritages in Gondar are the victims of this kind of problem.

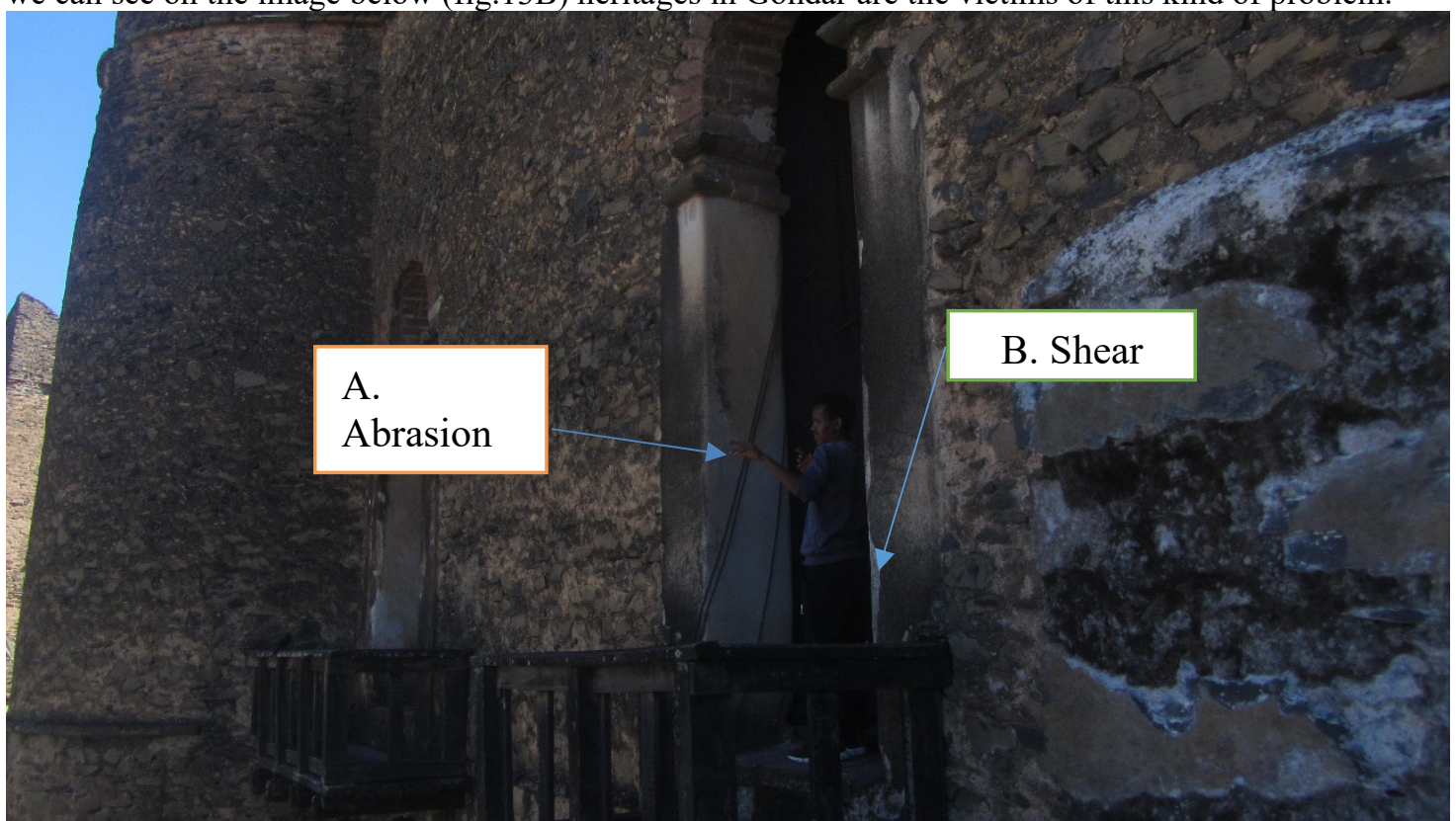

Fig 13(A.), Abrasion of the structure at Fasil palace and (B), shear of the structure at the same place.

\section{Improper Conservation}

Conservation is a problem if we are falling to do it properly. And if we are doing faults in conservation it is dangerous for the heritages; because heritages are irreplaceable human resources once we have lost them. There should not be try and error on heritages during conservation work. Having with this fact, the researcher has tried to assess the conservation work done on Gondar castles and the baths of world heritage sites. Accordingly, the Fasil bath has four gourd houses located in four directions. Originally, the purpose of these houses was for guarding. Now they(the conservator) have conserved and returned to its original nature physically. However, they tried to adapt and reuse the one guard house for toilet. The researcherbelieves as this way of adapt and reuse (conservation) is not faire and it is out of the science of conservation or it is improper and destructive.

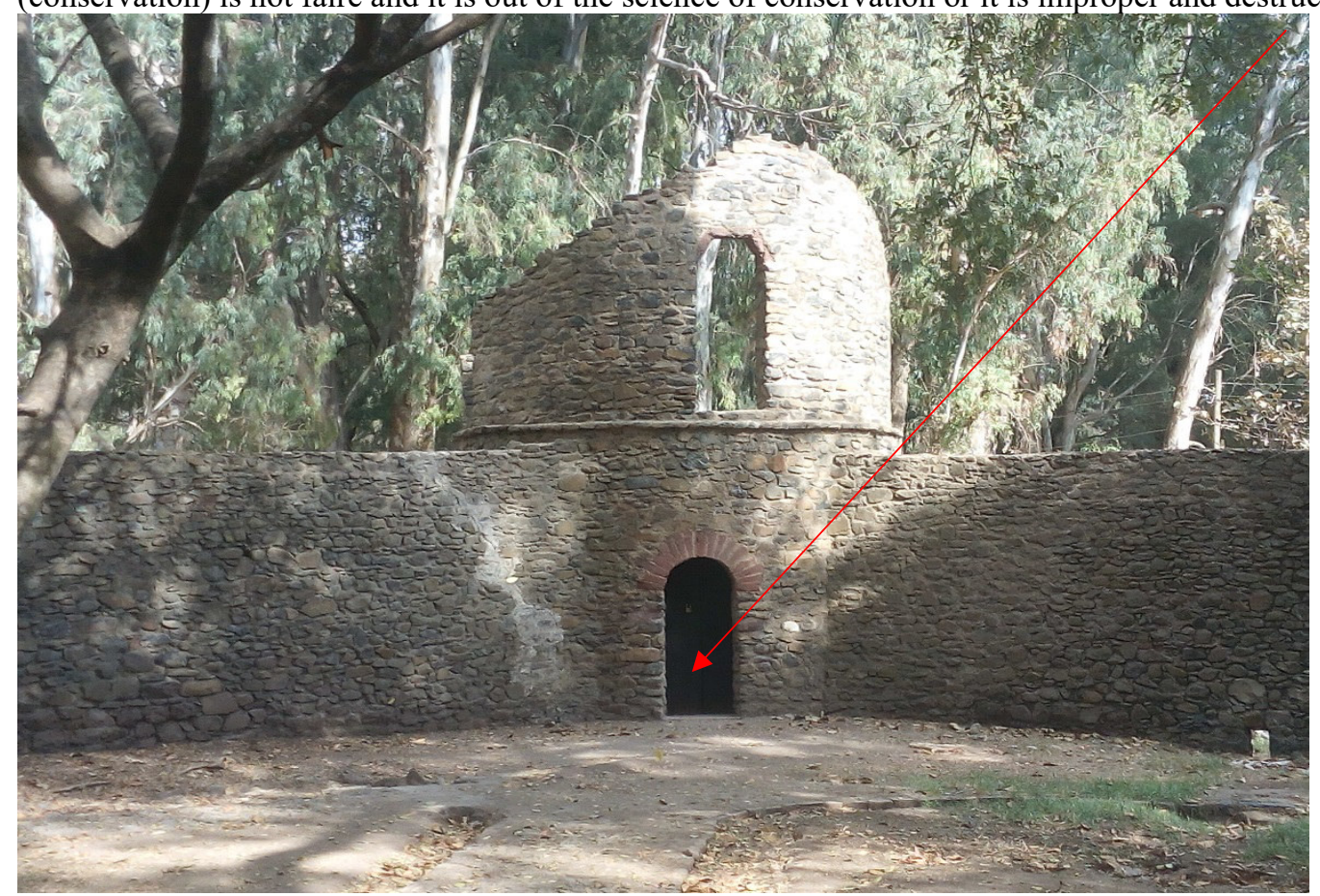

Fig. 14the guard house found on the south of the bath (Photo by the researcherFebruary, 2019)

The above displayed guard house was constructed in the south of the Fasil bath for guarding purpose and it is attached with the external fence of the bath. But now it is changed in to toilet. During the researcher'ssurvey it was locked (as the arrow showed on the image) and according to the guard, it is locked due to the lack of water. 
And he further stated that, every facility is prepared for the toilet and it was started its function for the aforementioned purpose. So, having with this fact let us see the principle of adaptive reusefroma quote "Adaptive Reuse: Preserving our past, building our future (2004)" Commonwealth of Australia, Department of Environment and Heritage:

The adaptive reuse of a historic building should have minimal impact on the heritage significance of the building and its setting. Developers should gain an understanding of why the building has heritage status, and then pursue development that is sympathetic to the building to give it a new purpose. Adaptive reuse is self-defeating if it fails to protect the building's heritage values. The most successfully developed heritage adaptive reuse projects are those that respect and retain the building's heritage significance and add a contemporary layer that provides value for the future.

According to the above argument, adaptive reuse is self-defeating if it fails to protect the building's heritage values. This means the developer should not disturb or change the heritage value of the historic structure. It is also advisable when adaptive reuse of a building is the only way to sustain the building and should not be a problem for the environmental settings. However, in the case of Fasil's bath guard house is now changed to toilet. That means the original value of the guard house is totally changed. And the new function of the house by itself is destructive for the heritage and disturbs the surrounding environment. So, the work is done in contradict with the principle of adaptive reuse.

\section{Inapplicability or Nonexistence of Heritage Management Plan}

According to the "Operational Guidelines for the Implementation of the World Heritage Convention"2005 (Paragraph 132, 5)the format for the nomination of properties for inscription on the World Heritage List should include "the list of the legislative, regulatory, contractual, planning, institutional and/or traditional measures most relevant to the protection of the property and provide a detailed analysis of the way in which this protection actually operates.

Accordingly, every world heritage sites should have a management plan for the effectiveness of its management work. Within the management plan there should be a clear demarcation for each zone stated in the above. However, in the case of Gondar the sites have no this boundary or no heritage management plan. Due to this reason various destructive activities are disturbing the sites.

\section{DeliberateGraffiti}

Heritages can begradually modified by an uncontrolled diffusion of graffiti and it is a form of vandalism (Licchelli et al., andCiliberto et al., 2013). This means graffiti can considered as vandalism of heritages and it is the result of lack of proper tourist follow-up system.

In the case of heritages in Gondar town, except selling of tickets at the entrances; no follow up of tourists after they enter to the enclosure. Particularly in the castles, no body follow-up the visitors; what they are doing inside. Due to this problem visitors made agraffiti (strike and incise) on the wall and write their name and sign their signature on the wall. As we can see on the image below, the names written with strike strongly spoiled/damaged the surface of the wall. The image shown at " $C$ " is the name written on the wooden part of the wall. So, this problem is affecting not only on the plastering wall, but also on the wooden part of the structure.

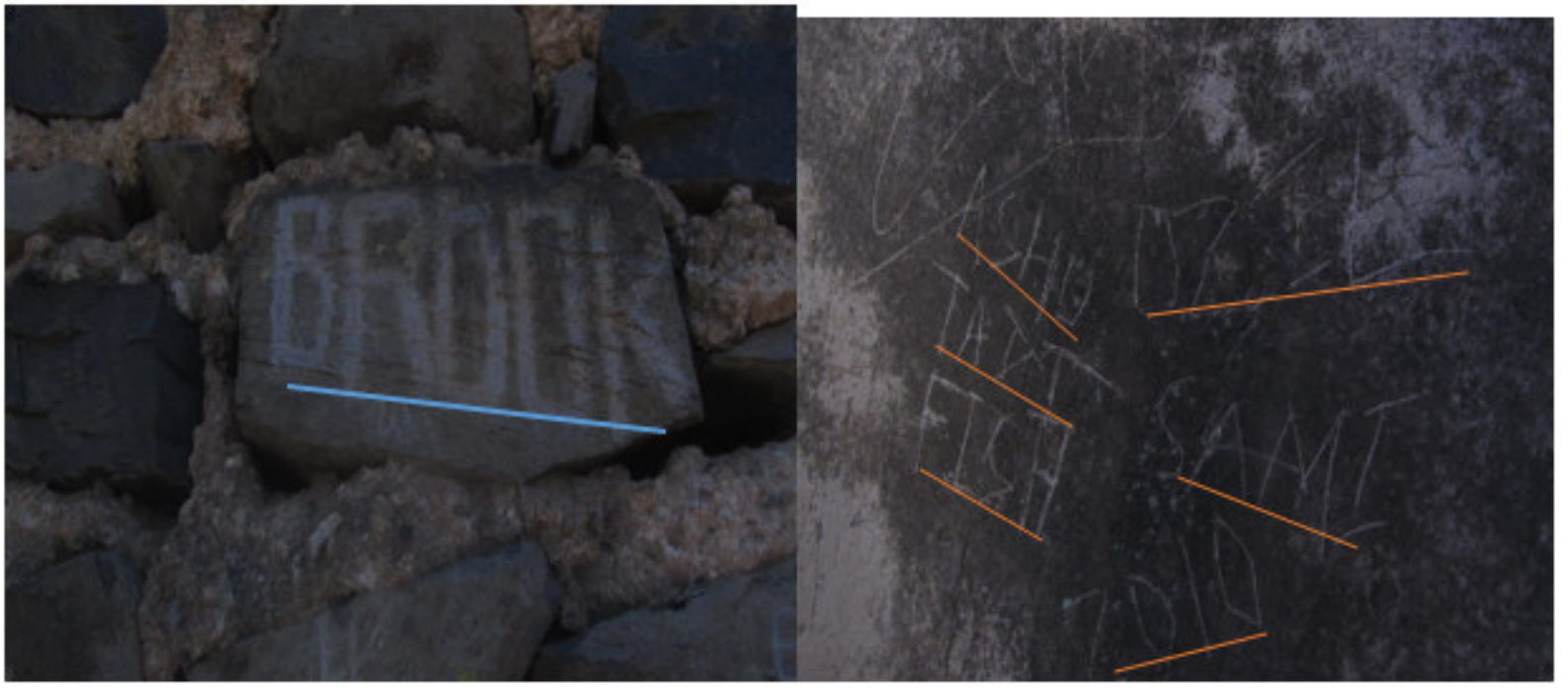

Fig15. .A. Strike and written name(BROOK) on the external wall of the then archival center B. Strike and names (ASHU, OZIL, TADI, SAMI, FISH and ZOLO) of the visitors on the plastering of eternal wall of theFasilbath 


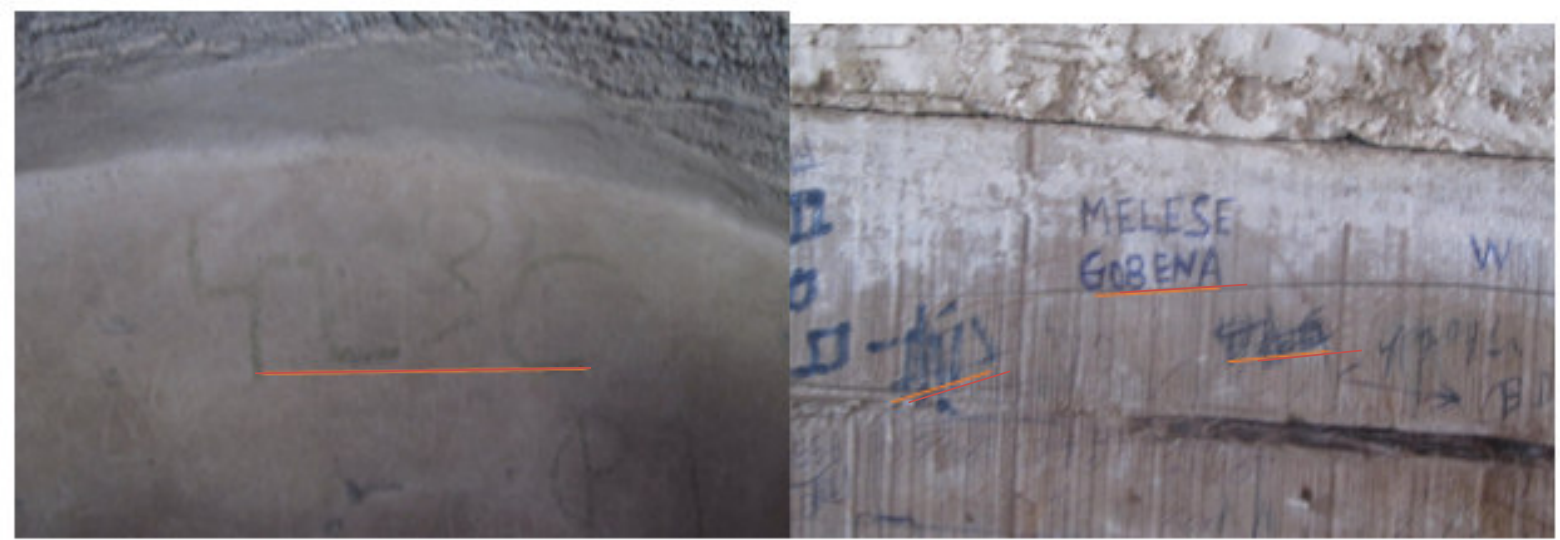

C. Written name $(\mathrm{h}, \rho \mathrm{C})$ by striking on the plastering ceiling of the bathe of FasilGehebbi and D. Again strike, written names (MELESE GOBENA) and signatures on the eternal ceiling of Emperor Bakafa'scastle (Photo by the researcher, December 2018).

Beside of the strikes stated and shown above, incised on the wooden part of the structures also another issue which is a threat for the heritages in Gondar town resulting through failing to follow-up visitors during their visit. The image below (A\&B) shown on the encircled and arrow indicates that visitors are incised their names on the plastered wall and wood.

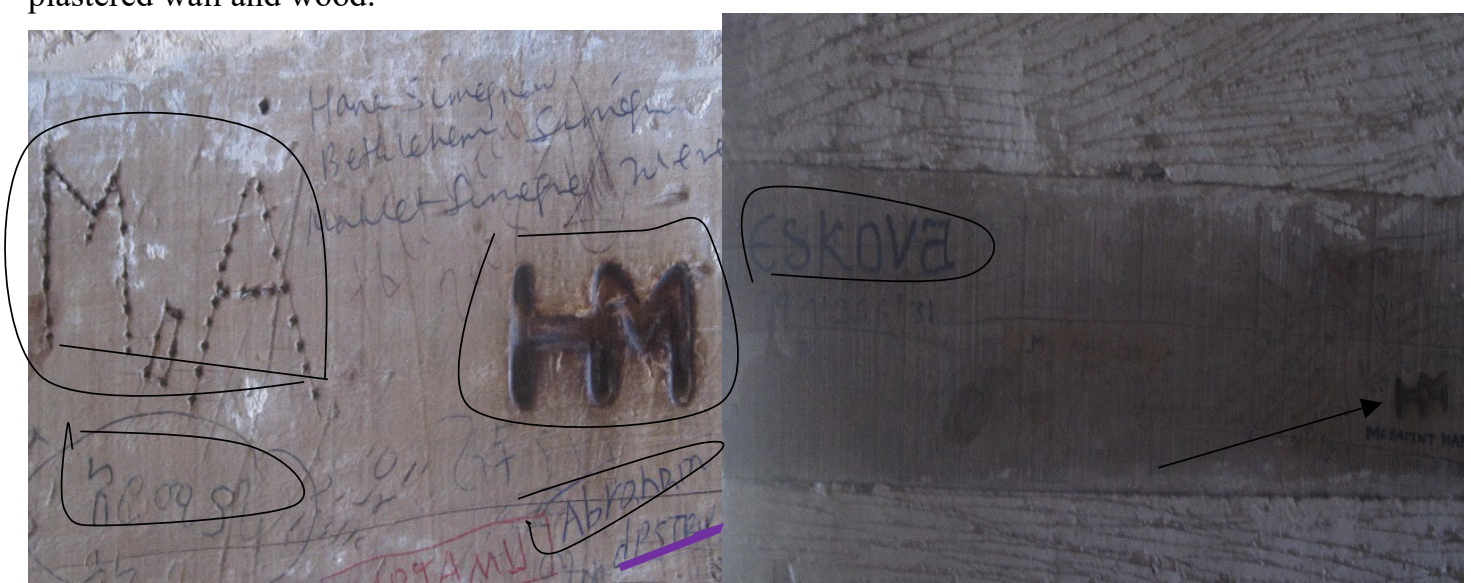

Fig.16 A. Names and abbreviations incised on the plastered surface of the eternal wall of emperor Bakafa's palace and B. The abbreviation (HM) shown by the arrow incised on the wooden part of the same palace with figure A.

According to John Mink, (2009), world heritage sites can be inscribed on the UNESCO's endangered list due to the above stated problems. Nazca Lines world heritage site of Peru was one of the most 5 endangered sites in the world list due to reckless tourism that causes deliberate graffiti since 2009.

..... As for the massive Nazca Lines themselves, they face severe damage both from increasing local use of the land and the impact of reckless tourism. Careless tourists in rental vehicles have been illegally driving off the established roads on this flat, dry shale terrain, scratching their own wheel tracks across 2000 year-old geoglyphs. Deliberate graffiti has occurred as well, with several remote geoglyphs being vandalized and new ones being carved in disturbing proximity to ancient artworks.

Another example of graffiti is the case in Elephanta Caves (India, Hindu). As John Mink, (2009) further stated that this world heritage site also was one of the top 5 endangered world heritage sites in 2009. He stated the problem as follows with a justification photographically.

Unfortunately, visitor mistreatment of the caves and their sculptures goes back many centuries. The Portuguese used the sculptures as target practice during the 17th century, and subsequent colonial regimes treated the ancient masterpieces little better. While the modern state of India has more respect for the sacred nature and value of these temples, Elephanta's close proximity to Mumbai and international reputation as a masterpiece has made for an unsustainable level of tourism. Very little conservation work or effective crowd control has been conducted by the authorities; as a result the already-damaged sculptures are in grave danger of further degradation. 


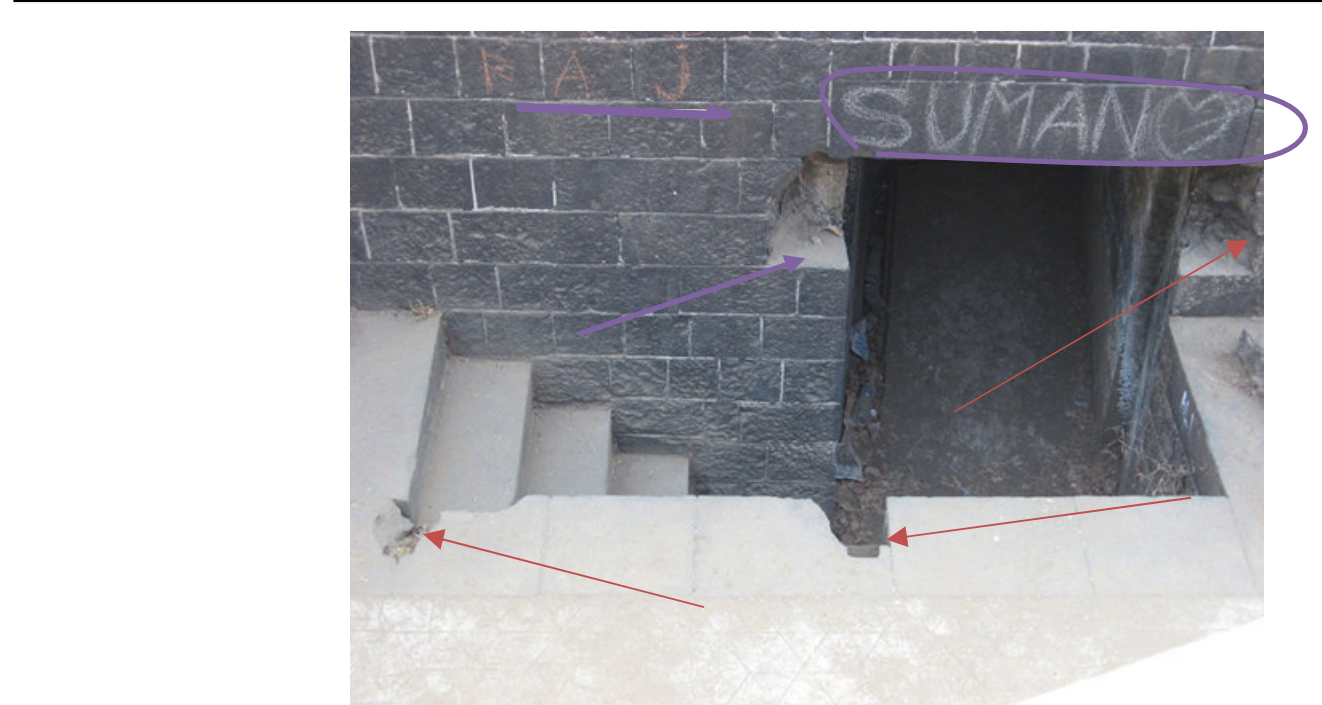

Fig. 17Photo of graffiti at Elephanta caves tunnel (taken from John Mink, 2009 available online)

So, as it is stated on the above 2 casesstudies, such kind of problems are caused by massive tourism with lack of proper follow up on heritages. Those 2 heritages were the top 5 endangered world heritages in 2009. It is to mean that, the same threat is challenging heritages in Gondar and it may leadthe sites to the endangered list of world heritage.

\section{Lack of Cooperation with the Concerned Bodies}

Heritage by its nature needs multidisciplinary study and cooperation of all the concerned bodies for itsproperup keeping. Professional from different field of study, individuals, governmental and nongovernmental institutions, religious institutions, and even now countries from different corner of the world (for world heritage sites) is expected to cooperate for the sustainable conservation and management of heritage sites.

However, the fact in the study area is the reverse. All the concerned bodies are not cooperating in preserving of this world heritage sites. Tourism offices in different level, municipality offices, land administration offices, mayor office of the town, universities, and construction offices are not working together. For example, if they work together the road may not be constructed on the immediate vicinity of the site. Doweling houses may not be constructed onheritages and the public baths may not be buried with dusts. Square may not be found very near to the castles. Road may not be constructed under the historic bridge and cars may not be pass under that historic bridge. The developers and urban planners are not consulting the heritage professionals and heritage conservators and managers also failing to cooperate with the stakeholders of these heritages.So, it is a serious issue that all concerned bodies should think over it.

\section{Unavailability of Directions and Instructions}

In Gondar, sites have no directions to show the ways outside or inside the sites. It will be better if the name of the site withitsdescriptions on the signboard at the entrance. However there is no such kind of directions in the sites of Gondar. Besides, there is no "Dos" and "Don't Dos" posted inside the enclosure except somewhere it

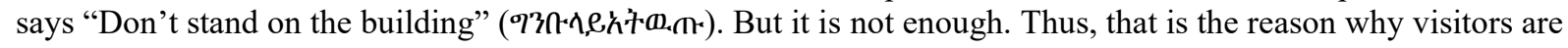
standing on the fragile part of the structure and having photo there. There are also very fragile parts of the structure which is not needed even to touch it. But, there are no any instructions which ordered the visitor to don't touch it. Again this is the reason why tourists are making graffiti on the surface and wooden part of the structures. In general, directions which direct the visitors and instructions about what they can do and cannot do should be clearly stated and posted.

\section{Conclusion and Recommendation/way of forward}

\section{Conclusion}

In line with the main findings of this investigation, Gondar's,FasilGhibbiCastles and the baths of world heritage sites are going to be under vicious circle of endanger. Multi-dimensional problems are sandwiched and touted the heritages. According to the comparison done with heritage sites of the world which was under endangered list; such kind of problems was the reason to inscribe them in the aforementioned list. Accordingly, the same kismet/fate is happening to the sites.

Plant overgrowth, human activities on the immediate vicinity of the site that leads to the vibration of the aged structures and noise disturbance, neglect/carelessness about the sites, visitors pressure (particularly the domestic tourists during epiphany, wedding and other events), absence of visitor follow up system that leads to deliberate graffiti of the heritage, improper heritage conservation, inapplicability or nonexistence of heritage management plan, unavailability of directions and instructions for visitorsand falling to work in collaboration 
with all the concerned bodies are the existing challenges of Gondar world heritage sites.

In a nutshell, they seek immediate or top urgent intervention to tackle the destruction. If these problems continued or if we are falling to solve, the propertieswill be in a serious destruction. That means it will lose its heritage values extremely. Again, if it lost its heritage values, there will not be tourism,history,economic gain and social values. All things will be stopped through time due to the haphazardly handling system of these heritage sites.

\section{Recommendations}

The small trees and grasses grown on the historic structures should be cleaned and better to have a permanent solution. The solution might be the culture and tourism office shallrecruita person who specializes in heritage conservation to clean and control the heritages permanently. In regarding to the big trees, the researcher strongly recommended to cut the trees before damaging the other part of the structure. Then after reconstruct or restore the structures already damaged through this case.

In regarding to roads, squares, parking and other human activities near the site, all the concerned bodies including heritage professionals, municipality and construction offices and culture and tourism office should work together on the this problem. The flow of vans, events on the square, parking almost on the site and cars pass through the historic bridge must be urgently stopped. The settlements almost on the site or nearby and the craps disposed on heritages also needs urgent intervention and stop it. So, the aforementioned stakeholders must introduce a new legislation or law to restrict and stop the human activities that affects the heritage resources.

Professionals and concerned institutions must give a due attention for the neglected heritages. The researcher believes that, the public bath located above the Fasil bath needs archaeological excavation and the institutions should work in relocation of settlements over the baths.

A number of visitors in a time should be specified or restricted. As it is stated in the main body, the domestic tourism including number of visitors during wedding should be restrict. During epiphany and other events, it is better to have a way that accommodates the visitors without affecting the site.

Tourist-follow up system also mandatory and it might be in the form of installing a hidden camera or follow up the visitors in person. In doing so, we can minimize or avoid illegal activities inside the sites by the visitors who visit the site without guide.

Applicable heritage management plan should be prepared and apply practically soon. If, there is a plan prepared before; it is advisable to apply it in solving the problems originated from its absence.

Conservation work should not be in contradicted with its science or should not be destructive. Conservators shall consult the professionals in the area. In the case of the adaptive re-use at Fasil bath all the materials for the installation of toilet in a historic structure should out and make it free or better to adapt and reuse for nondestructive purpose.

Sign board at the entrance to show the inside map of the castle is needed. In parallel with that, things allowed to do and not to do should be posted somewhere at the entrance. Some sensitive place needs to be identified and prohibit for visitors and it should be known for them. For example, in ground plus one floor of the Fasilpalace urgently needs some restrictions. Photo on the wooden window is a serious problem and needs immediate restriction.

As a sire action, since heritage needs cooperationfrom professionals, local peoples, government institutesand NGOs; needs endeavoring and contributing our share in saving of our identity.

\section{References}

- Adaptive Reuse: Preserving our past, building our future (2004). Commonwealth of Australia, Department of Environment and Heritage.

- Dugulan D., Balaure V., Popescu I.C., and C. Veghes (2010). "Cultural Heritage, NaturalResourcesand Competitiveness of the Travel and Tourism Industry in Central andEasternEuropean Countries", AnnalesUniversitatisApulensis Series Oeconomica, Vol. 2, No. 12, pp.742-748.

- EsraYaldiz, (2010).Climate Effects on Monumental Buildings. NecmettinErbakan University. Engineering Faculty of Architecture, Department of Architecture Konya, Turkey.

- Fikadu K. (2012).Building archaeology: The pre-Gondarine Monuments in West Gojam. Addis Ababa University, school of Graduate, unpublished MA thesis.

- Firas Alawneh1, etl. (2012). Environmental pollution, a threat to the archaeological sites, heritage and tourism in Zarqa, Jordan. Queen Rania's Institute of Tourism and Heritage; the Hashemite University.

- Huibin X., Marzuki A. and A. A. Razak (2012). "Protective Development of cultural heritagetourism: The case of Lijiang, China", theoretical and empirical researches in urbanmanagement, Vol. 7, No. 1, p.p.39-54.

- John Mink, (2009). 5 Sites at High Risk from the Hazards Associated with Large-Scale Visitor Traffic. 
CyArk.

- Licchelli et al., andCiliberto et al., (2013).Graphic Vandalism: Study of the Interaction of Spray Varnishes with Stone Materials and Test of some Anti-graffiti Treatments. University of Catania, Italy. Published at Elsevier.

- "Operational Guidelines for the Implementation of the World Heritage Convention", 2005. Seehttp://whc.unesco.org/en/guidelines online.

- Yoichi and Nishiyama. (1993). "Effect of air pollution on Cultural Properties."Bullitin of Research Institute NARA Institute Japan 1 (1): 101-114. 